\title{
7
}

\section{The Contribution of Fibronectin ED-A Expression to Myofibroblast Transdifferentiation in Diabetic Renal Fibrosis}

\author{
Keisuke Ina, Hirokazu Kitamura, \\ Shuji Tatsukawa and Yoshihisa Fujikura \\ Oita University \\ Japan
}

\section{Introduction}

The number of cases in which hemodialysis therapy for diabetic nephropathy is required has been increasing. Currently, the goal of treatment for renal fibrosis is not only to prevent the development and progression of the disease, but also to promote its remission and regression.

It is well known that glomerulosclerosis and tubulointerstitial fibrosis occur during the early stages of diabetic nephropathy. It has been demonstrated that the development of tubulointerstitial lesions is more closely correlated with a progressive decline in renal function compared to glomerular lesions (Bohle et al., 1991). Tubulointerstitial fibrosis ultimately leads to renal failure as a result of renal atrophy. The myofibroblasts emerging in tubulointerstitial fibrosis tissue have been indicated to play a crucial role in the development and progression of fibrosis (Simonson, 2007). They overproduce extracellular matrix (ECM) molecules, including type I collagen and fibronectin, and repress ECM degradation through the production of tissue inhibitor of metalloproteinase1 (TIMP-1) (Edwards et al., 1987) and plasminogen activator inhibitor-1 (PAI-1) in response to transforming growth factor- $\beta_{1}$ (TGF- $\left.\beta_{1}\right)$, which is increased in DN (Laiho et al., 1987), followed by ECM accumulation (i.e. fibrosis). Furthermore, the myofibroblasts may induce fibrosis tissue contraction via increased cell contraction promoted by asmooth muscle actin (a-SMA) expression, leading to renal atrophy and failure. Myofibroblasts are considered to be derived from various kinds of cells, e.g. fibroblasts (Strutz and Zeisberg, 2006), epithelial cells (Iwano et al., 2002), endothelial cells (Zeisberg et al., 2008), pericytes (Humphreys et al., 2010), and bone marrow-originated cells (Keeley et al., 2010), via stimulation by TGF- $\beta_{1}$.

Although a-SMA expression, which is the most pronounced characteristic of myofibroblasts, has been considered to cause tissue contraction, the detailed mechanism has not yet been determined. Myofiboblasts were first described in wound-healing granulation tissue 
(Gabbiani et al., 1971), where they were referred to as "modified fibroblasts" on the basis of their ultrastructural identification in transmission electron microscopic studies. These cells include a fibrillar system corresponding to stress fibers, nuclear indentation implying cell contraction, and cell-to-ECM and cell-to-cell junctions. Thus, modified fibroblasts (myofibroblasts) were described as an intermediate type of cell between fibroblasts and smooth muscle cells due to their ability to produce ECM and contract. Later investigators have noted that a-SMA expression in the stress fibers was the major characteristic of myofibroblasts.

At present, cells with a-SMA-positive stress fibers in the interstitium, except for vascular components, are recognized to be myofibroblasts. In vertebrate tissues, six actin isoforms have been identified. Four actin isoforms, including the a-skeletal, a-cardiac, a-vascular and $\gamma$-enteric isoforms, are tissue-restricted and involved in cell contraction. The other two actin isoforms, the $\beta$-cytoplasmic and $\gamma$-cytoplasmic isoforms, are ubiquitously expressed. These have been considered to constitute noncontractile cytoskeletons. The a-vascular actin is the SMA isoform, referred to as "a-SMA". During myofibroblast transdifferentiation, the actin isoform transitions, at least in part, from the cytosolic actin to a-SMA. It has been proposed that myofibroblasts have the ability to contract due to their expression of a-SMA.

Fibronectin, a $440 \mathrm{kDa}$ dimeric glycoprotein, is one of the ECM molecules that exerts various functions, including adhesion, migration and differentiation. The fibronectin subunit is composed of three internally homologous repeats and contains binding sites for cell surface receptors and for other ECM components (Magnusson \& Mosher, 1998; Peterson et al., 1983). Fibronectin polymorphisms arise from the alternative splicing of mRNA at three regions, ED-A, ED-B and IIICS (Norton \& Hynes, 1987) (Fig. 1). The two former sequences are either omitted or included, while the latter one varies in length. Fibronectins are present in an insoluble form in the ECM, and in a soluble form in circulation, namely as cellular fibronectin and plasma fibronectin. Only cellular fibronectin contains ED-A and EDB (Vartio et al., 1987). The fibronectin ED-A and fibronectin ED-B isoforms are predominantly expressed in embryonic tissue, and are seldom found in normal adult tissues. However, fibronectin ED-A has been demonstrated to be re-expressed in a variety of reactive and pathological processes, such as wound healing (Ffrench-Constant et al., 1989), arterial internal thickening (Glukhova et al., 1989) and liver fibrosis (Jamagin et al., 1994). In vitro, TGF- $\beta_{1}$ has been shown to increase fibronectin production, and it regulates the splicing pattern of fibronectin pre-messenger RNA, followed by expression of the ED-A domain (Balza et al., 1988; Borsi et al., 1990). Moreover, it has been suggested that the fibronectin ED-A isoform modulates various cells to generate myofibroblasts which express a-SMA (Bochaton-Piallat et al., 2000; Ffrench-Constant et al., 1989; Jamagin et al., 1994). Gabbiani and coworkers demonstrated that the fibronectin ED-A isoform plays a crucial role in TGF$\beta_{1}$-induced myofibroblast transdifferentiation in an in vitro study using human subcutaneous fibroblasts (Serini et al., 1998).

In the present study, we examined whether TGF- $\beta_{1}$ induces the expression of the ED-A domain in fibronectin, and whether this, in turn, leads to a-SMA expression in renal fibroblasts by using an in vitro model of fibrosis due to diabetic nephropathy. Furthermore, whether the fibronectin ED-A isoform stimulates the contraction of the collagen gel through the expression of a-SMA and the accumulation of type I collagen was examined. 


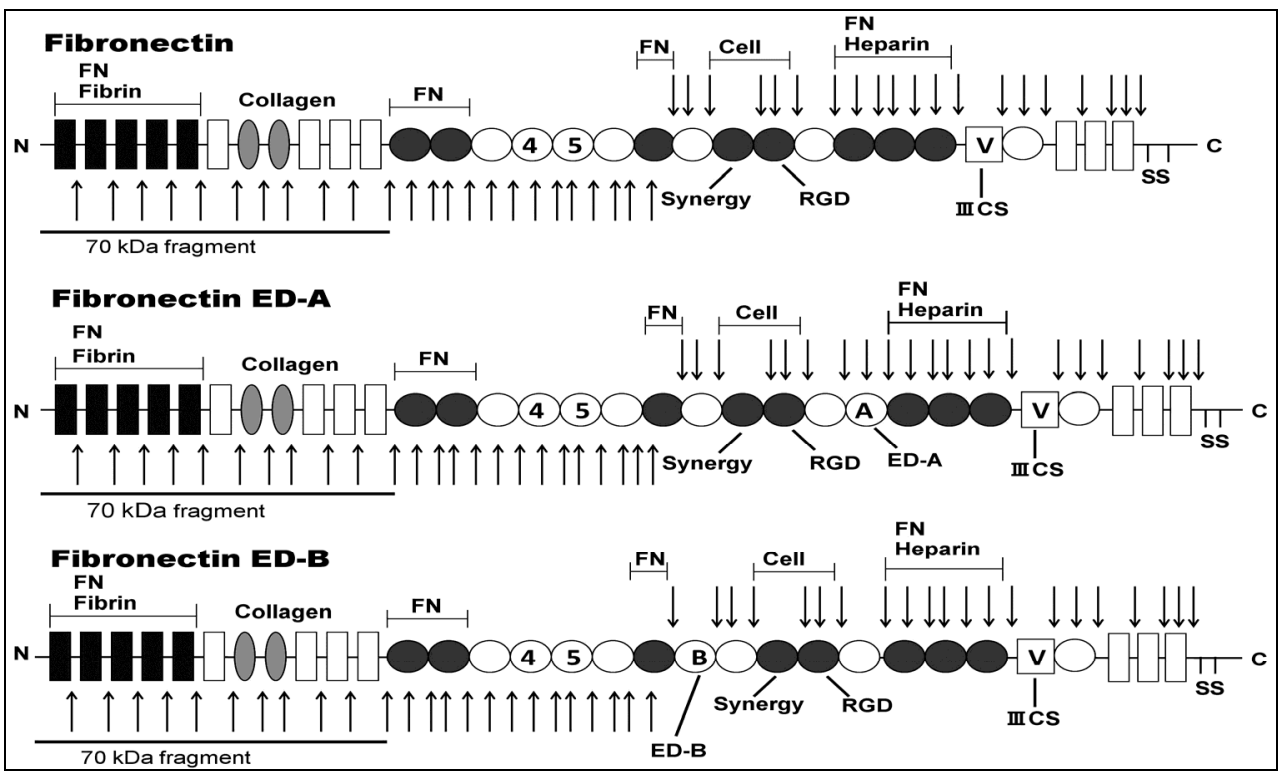

Fig. 1. The molecular structure of fibronectin ED-A and ED-B.

The fibronectin subunit is composed of three different repeating sequences: type I (rectangles), type II (ovals) and type III (circles). Sets of repeats constitute binding domains for fibrin, fibronectin (FN), collagen, cells and heparin as described. Sequence variations can occur in all three points of the fibronectin subunit: extra domains A and B (ED-A and ED-B, respectively) and the IIICS (Wierzbicka-Patynowski \& Schwarzbauer, 2003). Allows indicate approximate intron positions determined in the murine gene.

\section{Materials and methods}

\subsection{Materials}

Porcine type I collagen solution was purchased from Nitta Gelatin (Osaka, Japan), recombinant human TGF- $\beta_{1}$ was purchased from $\mathrm{R}$ and D Systems (MN, USA), and the mouse monoclonal antibodies against a-SMA and ED-A were obtained from Sigma-Aldrich (MO, USA) and Abcam (Cambridge, UK), respectively. The fluorescein isothiocyanate (FITC)-conjugated goat anti-mouse IgG secondary antibody against these monoclonal antibodies was purchased from Caltag Laboratories (CA, USA). Rat type I collagen ELISA kits were obtained from Cusabio (Wuhan, China).

\subsection{Cell culture}

Normal rat kidney fibroblasts (NRK 49F cells) were obtained from the RIKEN Cell Bank (Tsukuba, Japan). The cells were maintained in Dulbecco's minimal essential medium (DMEM) (Nissui Pharmaceutical, Tokyo, Japan) containing $100 \mathrm{IU} \mathrm{ml}^{-1}$ penicillin, $100 \mu \mathrm{g} \mathrm{ml}^{-1}$ streptomycin, and $10 \%$ fetal bovine serum (FBS) (JRH Biosciences, KS) at $37^{\circ} \mathrm{C}$ in a humidified, $5 \% \mathrm{CO}_{2}$ atmosphere. FBS had been heat-inactivated at $56^{\circ} \mathrm{C}$ for $30 \mathrm{~min}$ prior to use. Cells from passage 3 to passage 8 were used in the experiments described below. 
Monolayer cultures of $2 \times 10^{4}$ cells $\mathrm{ml}^{-1}$ were grown on two-well Labtek Chamber Slides (AS ONE, Osaka, Japan). The cell cultures were divided into 4 groups: a control group, cultured with $0.5 \%$ FBS; a TGF- $\beta_{1}$ group, cultured with $0.5 \%$ FBS $+5 \mathrm{ng} \mathrm{ml}^{-1}$ TGF- $\beta_{1}$; an anti-ED-A antibody group, cultured with $0.5 \%$ FBS $+5 \mathrm{ng} \mathrm{ml}^{-1}$ TGF- $\beta_{1}+10 \mu \mathrm{g} \mathrm{ml}^{-1}$ anti-ED-A antibody; an IgG group, cultured with $0.5 \% \mathrm{FBS}+5 \mathrm{ng} \mathrm{ml}^{-1} \mathrm{TGF}-\beta_{1}+10 \mu \mathrm{g} \mathrm{ml}^{-1}$ mouse IgG (negative control, R \&D Systems, Inc., MN, USA). Furthermore, each group was sub-divided into two groups: the 1D (1 day) group, which was cultured for $24 \mathrm{~h}$ after the initiation of culture; the $2 \mathrm{D}$ ( 2 day) group, which was cultured for $24 \mathrm{~h}$ after refeeding the cells the same medium 24 $\mathrm{h}$ after culture initiation. The cells and the supernatants of all groups were subjected to immunofluorescence studies for fibronectin ED-A or a-SMA, and to an ELISA for type I collagen, respectively.

\subsection{Immunofluorescence microscopy for fibronectin ED-A and $\alpha$-SMA}

The cells from monolayer cultures were fixed in $4 \%$ paraformaldehyde in $0.1 \mathrm{M}$ phosphatebuffered saline ( $\mathrm{pH}$ 7.4) for $10 \mathrm{~min}$. After rinsing, the cells were permeabilized with $0.5 \%$ Triton X-100 for $20 \mathrm{~min}$ in order to identify a-SMA in the cells, this process was omitted in studies for detecting fibronectin ED-A. After washing, the cells were incubated with the primary antibody against a-SMA or fibronectin ED-A for $2 \mathrm{~h}$ at room temperature. After being rinsed, they were incubated with FITC-conjugated goat anti-mouse IgG secondary antibody for $1 \mathrm{~h}$ at room temperature. After staining, the cells were rinsed, observed and photographed using an Olympus BX 60 microscope equipped with epifluorescence optics. The assessment of the percentage of cells with a-SMA-positive stress fibers was performed as follows: when there were one or more stress fibers with a-SMA-positive staining in a cell, the cell was considered to be a-SMA-positive and was referred to as a "myofibroblast". The percentage of myofibroblasts was represented by counting the a-SMA-positive cells among 100 to 500 cells.

\subsection{Gel contraction assay}

A total of $7 \mathrm{ml}$ of a collagen solution $(3 \mathrm{mg} / \mathrm{ml}$ stock) was gently mixed with $2 \mathrm{ml}$ of 5 -foldconcentrated D-MEM on ice. The mixture was adjusted to $\mathrm{pH} 7.4$ with $1 \mathrm{ml}$ of $200 \mathrm{mM}$ HEPES plus $2.2 \% \mathrm{NaHCO}_{3}$ in distilled water. This collagen mixture $(0.3 \mathrm{ml})$ was added to each well of a 24 well plate (Becton-Dickinson Labware, NJ). Then, the collagen gel was formed by the incubation of the mixture for $30 \mathrm{~min}$ at $37^{\circ} \mathrm{C}$. After gelatinization, an NRK 49F cell suspension $\left(2 \times 10^{4}\right.$ cells $\left.\mathrm{ml}^{-1}\right)$ was poured on the gel in each well. Preincubation of the cell-populated collagen lattice was performed in D-MEM $+10 \%$ FBS for $24 \mathrm{~h}$. Next, the gels were rinsed with serum-free D-MEM three times for $30 \mathrm{~min}$. Then, the gel cultures were divided into 4 groups similar to the immunofluorescence studies: a control group, cultured in $0.5 \%$ FBS; a TGF- $\beta_{1}$ group, cultured in $0.5 \%$ FBS $+5 \mathrm{ng} \mathrm{ml}^{-1}$ TGF- $\beta_{1}$; an anti-ED-A antibody group, cultured in $0.5 \%$ FBS $+5 \mathrm{ng} \mathrm{ml}^{-1}$ TGF- $\beta_{1}+10 \mu \mathrm{g} \mathrm{ml}^{-1}$ anti-ED-A antibody and an IgG group, cultured in $0.5 \% \mathrm{FBS}+5 \mathrm{ng} \mathrm{ml}^{-1} \mathrm{TGF}-\beta_{1}+10 \mu \mathrm{g} \mathrm{ml}^{-1}$ mouse IgG. The gels were then detached from the lateral wall and bottom of each well with a microspatula and cultured for $48 \mathrm{~h}$. After $48 \mathrm{~h}$ in culture, the diameter of each gel was measured with a ruler to assess the gel contraction after treatment with the reagents. In addition, to confirm that the shrinkage of the cell-populated collagen lattice occurred due to gel contraction, rather than gel digestion, another study was performed. For this study, after gelatinization, the 
NRK49F cell suspension ( 5000 cells per $5 \mu 1)$ was placed in a very small area near the margin of the gel, and incubated for $1 \mathrm{~h}$ at $37^{\circ} \mathrm{C}$. Then, preincubation was done as above. After rinsing, the gels were cultured in the control medium and the medium with $5 \mathrm{ng} \mathrm{ml}^{-1}$ TGF- $\beta_{1}$ for $48 \mathrm{~h}$ at $37^{\circ} \mathrm{C}$ following gel detachment. After $48 \mathrm{~h}$, the shapes of the gels were observed.

\subsection{Enzyme-linked immunosolvent assay for type I collagen accumulation in the supernatants of the cultures}

The supernatants from monolayer cultures were added to the wells of 96 well plate, which were pre-coated with a mouse monoclonal antibody against rat type I collagen, and were incubated for $2 \mathrm{~h}$ at $37^{\circ} \mathrm{C}$. After removing the liquid from each well, a biotin-conjugated anti-mouse IgG secondary antibody solution was added, and cells were incubated for $1 \mathrm{~h}$ at $37^{\circ} \mathrm{C}$. After rinsing, each well was exposed to the horseradish peroxidase-avidin solution for $1 \mathrm{~h}$ at $37^{\circ} \mathrm{C}$. After washing, the TMB substrate was added, and cells were incubated for 20 $\min$ at $37^{\circ} \mathrm{C}$. Then, the stop solution was added to each well, while the optical density of each well was determined using a microplate reader, the Multiskan GO (Thermo Fisher Scientific, Yokohama, Japan), at $450 \mathrm{~nm}$. The value of the optical density was converted to the type I collagen concentration in the supernatant of the monolayer culture.

\subsection{Statistical analysis}

The experimental data are presented as the means \pm SD. The statistical analyses were performed using Student's $t$-test. Differences were considered to be statistically significant at $\mathrm{P}<0.05$.

\section{Results}

\subsection{TGF- $\beta_{1}$ - induced the expression of ED-A and $\alpha-S M A$}

ED-A expression was induced in a dot or short linear pattern on the cell surface by TGF- $\beta_{1}$ by $24 \mathrm{~h}$ after initiation of culture (the 1D - TGF- $\beta_{1}$ group), and was further increased after the $48 \mathrm{~h}$ culture (the $2 \mathrm{D} \cdot \mathrm{TGF}-\beta_{1}$ group) (Figs. $2 \mathrm{c}, 2 \mathrm{~d}$ ). On the other hand, the expression of intracellular a-SMA was not observed $24 \mathrm{~h}$ after the initiation of culture (the 1D - TGF- $\beta_{1}$ group), but was induced in stress fiber formations after $48 \mathrm{~h}$ in culture (the $2 \mathrm{D} \cdot$ TGF- $\beta_{1}$ group) (Figs. 2g, 2h). The expression of ED-A and a-SMA was not observed in the cells cultured in the medium without TGF- $\beta_{1}$ (the 1D and 2D control groups) (Figs. 2a, 2b, 2e, 2f).

\subsection{The effects of the anti-ED-A antibody on TGF- $\beta_{1}$ - induced $\alpha$-SMA expression}

The TGF- $\beta_{1}$ - induced a-SMA expression was markedly decreased by adding an anti-ED-A antibody to the medium (Fig. 3A). The rates of a-SMA-positive cells in stress fiber formations were as follows: the $2 \mathrm{D}$ control group $(0 \%)$, the $2 \mathrm{D}$ TGF- $\beta_{1}$ group $(97 \%)$, the $2 \mathrm{D}$ anti-ED-A antibody group (36\%), and the 2D IgG group (95\%) (Fig. 3B).

\subsection{The characteristics of TGF- $\beta_{1}$-induced gel shrinkage}

When the cells were ubiquitously poured on the gel, TGF- $\beta_{1}$-induced gel shrinkage occurred in the shape of a circle after culture for $48 \mathrm{~h}$ (Fig. $4 \mathrm{Aa}$ ). The diameters of gels were $99.4 \pm 1.0 \%$ 


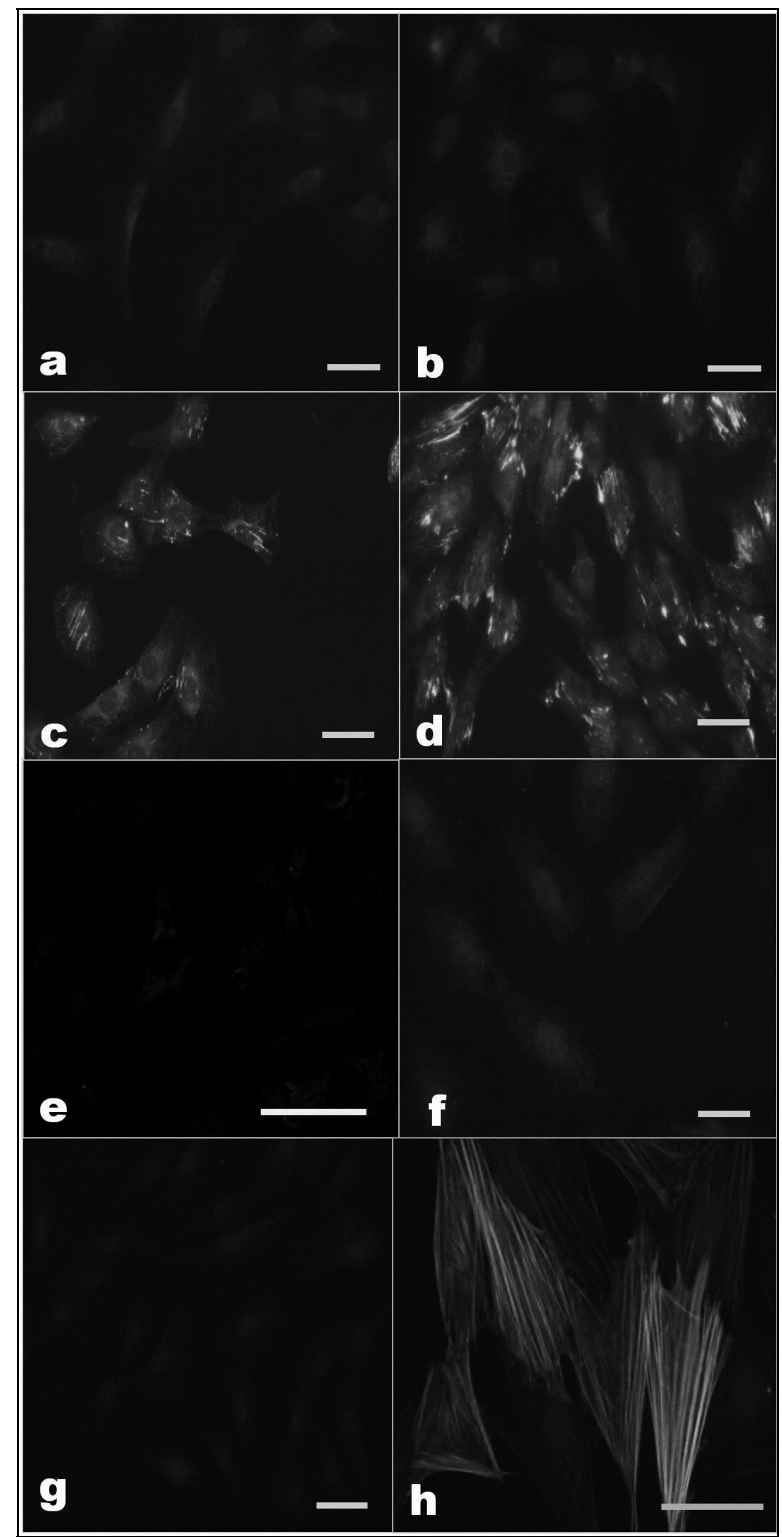

Fig. 2. Immunofluorescent staining for ED-A and a-SMA induced by TGF- $\beta_{1}$. a, c, e, g, ID groups; b, d, f, h, 2D groups; a, b, c, d, Immunostaining for ED-A; e, f, g, h, Immunostaining for a-SMA; $a, b$, e, f, control groups; $c, d, g$, h, TGF- $\beta_{1}$ groups. a, No immunostaining. $b$, No immunostaining. c, Immunostaining for ED-A is shown by the dot or short linear pattern on the cell surface. $d$, Immunostaining for ED-A was increased. e, No immunostaining. $f$, No immunostaining, g, No immunostaining. $h$, Immunostaining for aSMA is seen in the stress fiber formation in the cells. Bar, $10 \mu \mathrm{m}$. 
in the control medium group and $86.4 \pm 1.7 \%$ in the TGF- $\beta_{1}$ group $(\mathrm{p}<0.001)$ (Fig. $\left.4 \mathrm{Ab}\right)$. On the other hand, when the cells were placed in a small region close to the margin of the gel, the gel exhibited indentation toward the cell mass in response to TGF- $\beta_{1}$ (Fig. 4B). If gel shrinkage occurs due to gel digestion, the gel would reveal the features of digestion, such as the dissolution of the gel around the cell mass, and would form a thin layer or disappear. However, because the present study did not show these features, gel digestion was not considered to be responsible for the observed gel shrinkage. The observed indentation was thought to be caused by retraction of the gel resulting from cell contraction.

\subsection{The effects of the anti-ED-A antibody on TGF- $\beta_{1}$-induced gel contraction}

Gel contraction did not occur in the control medium throughout the experimental period. In addition, no gel contraction was observed in any of the 1D groups. In the 2D groups, TGF- $\beta_{1}$ remarkably evoked gel contraction. The treatment with the anti-ED-A antibody was shown to repress TGF- $\beta_{1}$-induced gel contraction. The diameters of the gels in the four groups were as follows: the $2 \mathrm{D}$ control group $(100 \%)$, the $2 \mathrm{D}$ TGF- $\beta_{1}$ group $(84.0 \pm 1.9 \%)$, the $2 \mathrm{D}$ anti-ED-A antibody group $\left(89.5 \pm 1.9 \%, \mathrm{p}<0.05\right.$ vs the $2 \mathrm{D}$ TGF $-\beta_{1}$ group), and the $2 \mathrm{D}$ IgG group ( $83.7 \pm 1.6 \%, \mathrm{p}<0.05$ vs the $2 \mathrm{D}$ anti-ED-A antibody group) (Fig. 5).

\subsection{The effects of the anti-ED-A antibody on TGF- $\beta_{1}$-stimulated type I collagen accumulation in the supernatants of the cell cultures}

There were no significant differences in the accumulation of type I collagen in the cell supernatants between the three 1D groups (the control group, $1420 \pm 200$; the TGF- $\beta_{1}$ group, $1470 \pm 100$; the anti-ED-A antibody group, $1510 \pm 160$; the IgG group, $1513 \pm 26 \mathrm{pg} \mathrm{ml}^{-1}$ ). In the $2 \mathrm{D}$ groups, the accumulation of type I collagen in the supernatant of the TGF- $\beta_{1}$ group was increased. The increased accumulation of collagen was repressed by addition of the anti-EDA antibody to the medium with TGF- $\beta_{1}$ (Fig. 5). The concentrations of the supernatants in the four 2D groups (control, TGF- $\beta_{1}$, anti-ED-A antibody, IgG) were $1980 \pm 220,2730 \pm 110$, $2490 \pm 18,2570 \pm 3 \mathrm{pg} \mathrm{ml}^{-1}$, respectively $\left(\mathrm{p}<0.001\right.$, the control group vs the TGF- $\beta_{1}$ group; $\mathrm{p}<0.05$, the TGF- $\beta_{1}$ group and the IgG group vs the anti-ED-A antibody group) (Fig. 6).

\section{Discussion}

Myofibroblasts expressing a-SMA have been shown to emerge in fibrotic diseases (Tomasek et al., 2002). In general, a-SMA is considered to be profoundly involved in the progression of fibrosis, but the detailed significance of a-SMA expression remains unresolved. For example, it is unclear whether myofibroblasts are really essential for fibrosis. In contrast to general considerations, there have been some reports indicating that myofibroblasts are not necessary for the progression of fibrosis. For example, Takeji et al. suggested that a-SMA expression provided benefits for fibrosis (Takeji et al., 2006). It was demonstrated that defects in a-SMA enhanced the progression of fibrosis by performing unilateral ureteral obstruction in a renal interstitial fibrosis model in an a-SMA knockout mouse. Furthermore, transfection of the a-SMA gene into a-SMA-/- myofibroblasts from these mice suppressed fibrosis. These results indicated that a-SMA expression suppresses, rather than accelerates, fibrosis. The a-SMA-/- myofibroblasts that were obtained possessed the ability to migrate, proliferate, and overproduced type I collagen. These cells did not express a-SMA, but did start to overexpress skeletal muscle a-actin, smooth muscle $\gamma$-actin, and related molecules. 
These cells also overproduced type I collagen compared to conventional myofibroblasts expressing a-SMA. Because the cells which were established by transfection of the a-SMA gene into the a-SMA-/- cells failed to produce type I collagen, these cells might resemble smooth muscle cells. It is likely that myofibroblasts are an intermediate type of cells between a-SMA-/- cells and smooth muscle cells, given their ability to express a-SMA and produce type I collagen. Taken together, their report does not refute the generally accepted concept

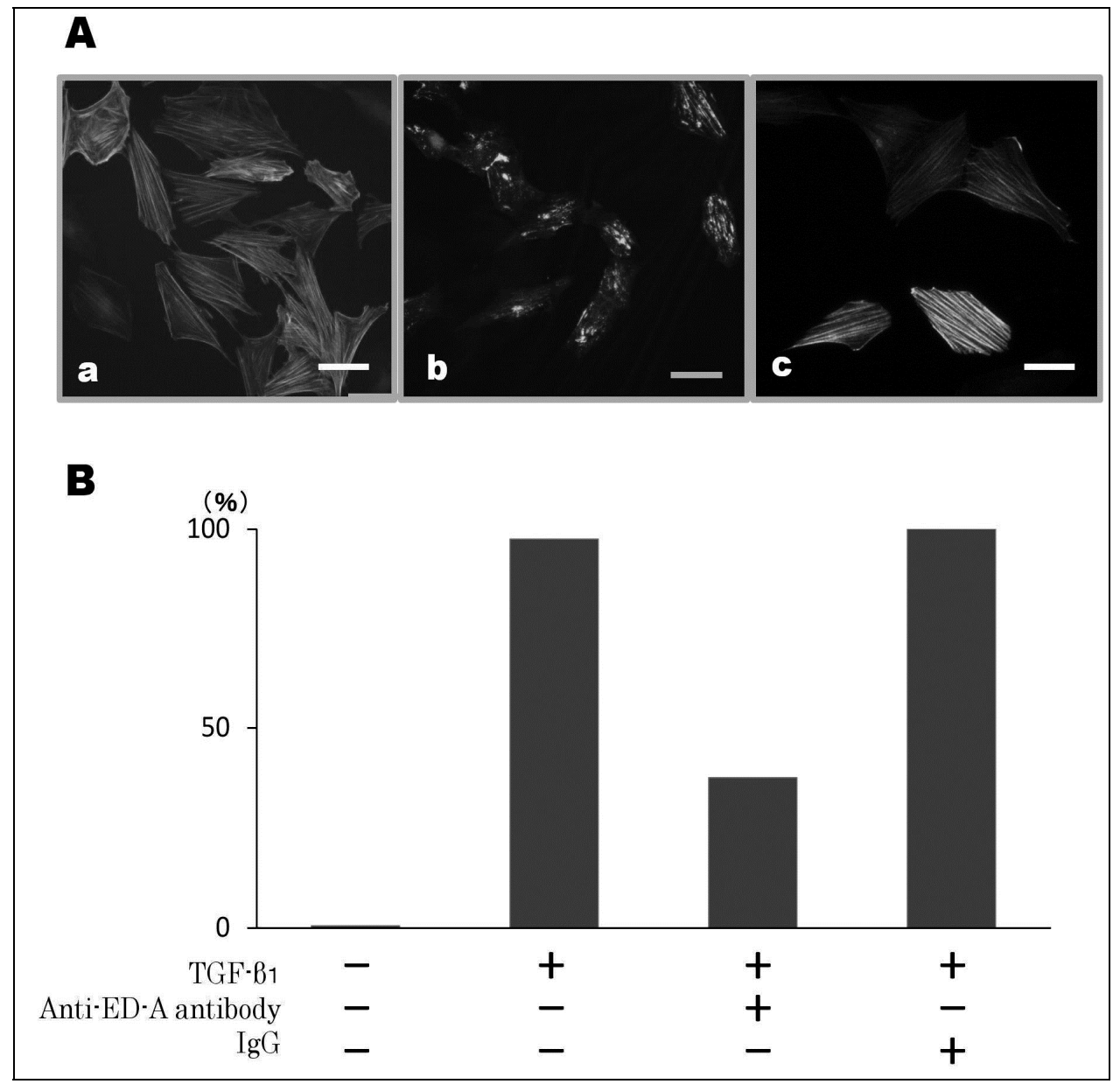

Fig. 3. Immunofluorescent staining for a-SMA was influenced by the anti-ED-A antibody $\mathrm{Aa}$, the $2 \mathrm{D}$ TGF- $\beta_{1}$ group; $\mathrm{b}$, the $2 \mathrm{D}$ anti-ED-A antibody group; $\mathrm{c}$, the $2 \mathrm{D}$ IgG group; $\mathrm{B}$, Counts of cells immunostained for a-SMA in the stress fiber formation. Aa and Ac, Immunostaining for a-SMA was shown in the stress fiber formation. Ab, Cells expressing a-SMA in the stress fiber formation were markedy decreased in number. Immunostaining for ED-A was seen in response to addition of the anti-ED-A antibody to the medium. B. Cells with a-SMA expression induced by TGF- $\beta_{1}$ were decreased in number in the anti-EDA antibody group. Bar, $10 \mu \mathrm{m}$. 


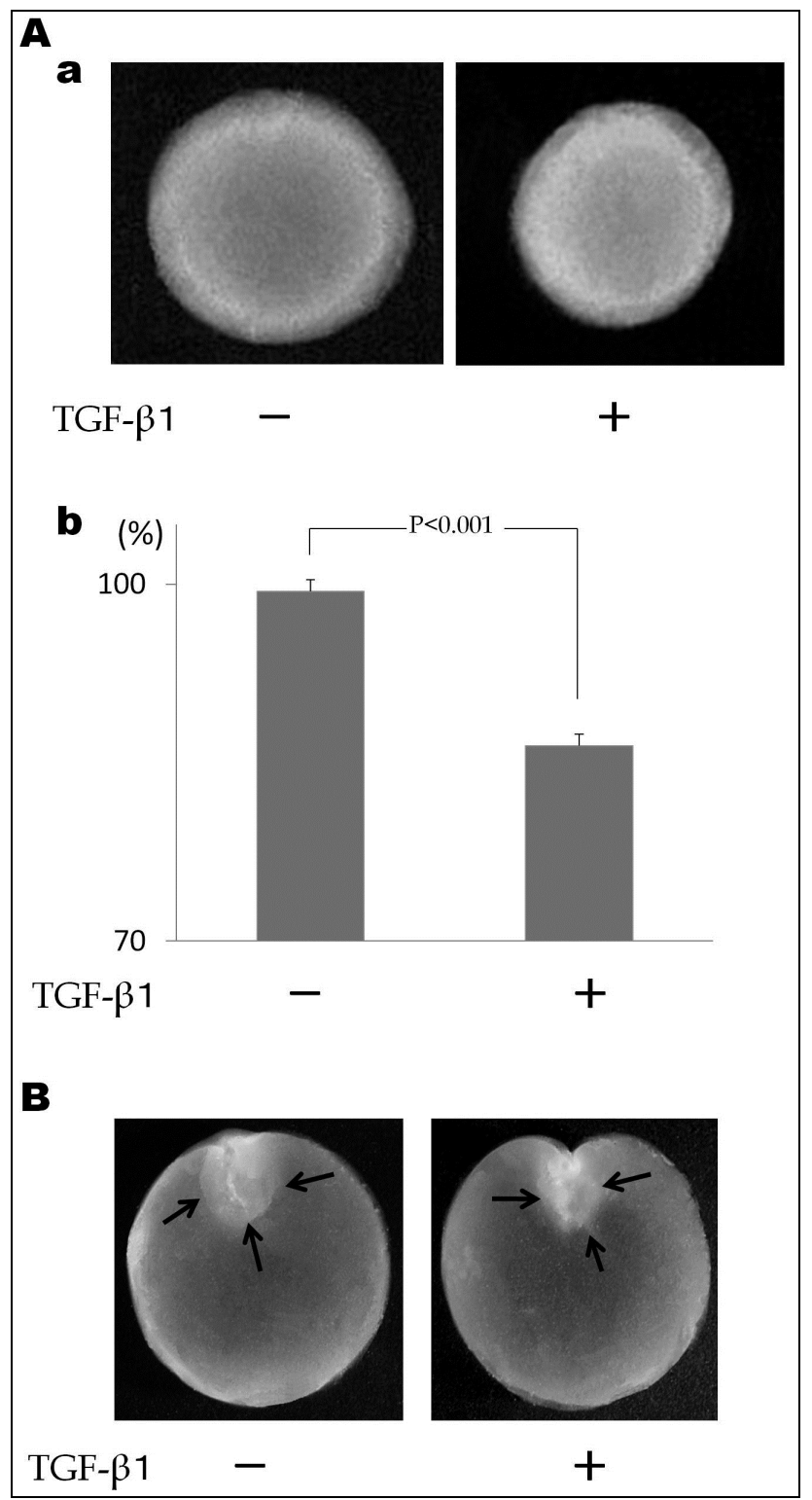

Fig. 4. Morphological alterations of gels in response to TGF- $\beta_{1}$ according to differences in the pouring methods.

A. Ubiquitous pouring of cells. a. The shape of the gel b. the diameters of the gels. B. Spot pouring of cells. Aa. The change in shape induced by TGF- $\beta_{1}$ is indicated by the circle. Ab. TGF- $\beta_{1}$ significantly induced gel shrinkage. The data represent the diameters of the gels compared to the well. B. The gel was deformed, as shown by the indentation torward the cell mass (arrows). 


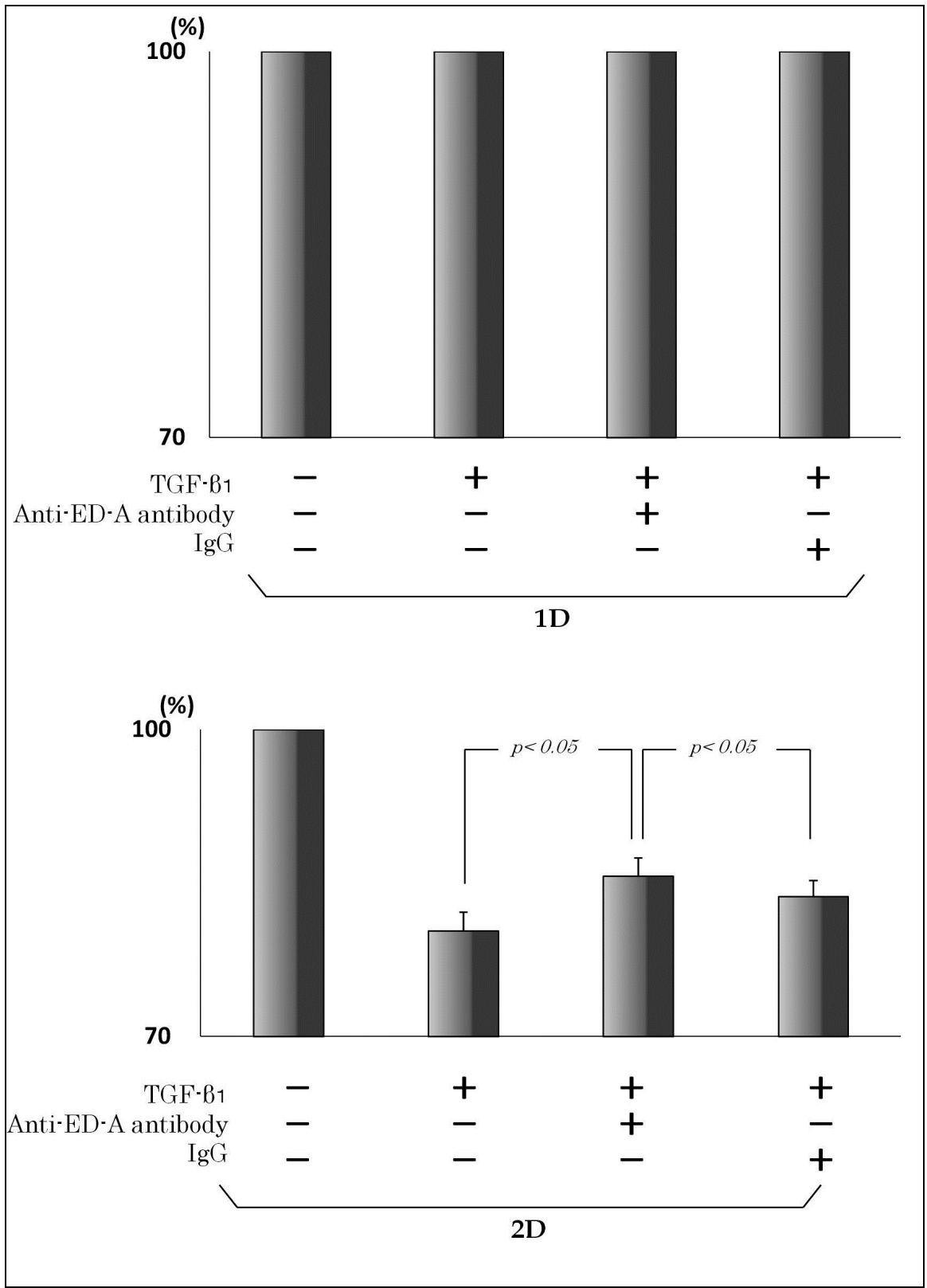

Fig. 5. Type I collagen gel contraction.

No gel contraction occurred in any of the $1 \mathrm{D}$ groups. TGF- $\beta_{1}$ was shown to evoke gel contraction in the 2 D TGF- $\beta_{1}$ and IgG groups. TGF- $\beta_{1}$-induced gel contraction was attenuated by adding the anti-ED-A antibody. The data represent the diameters of the gels compared to the well. 


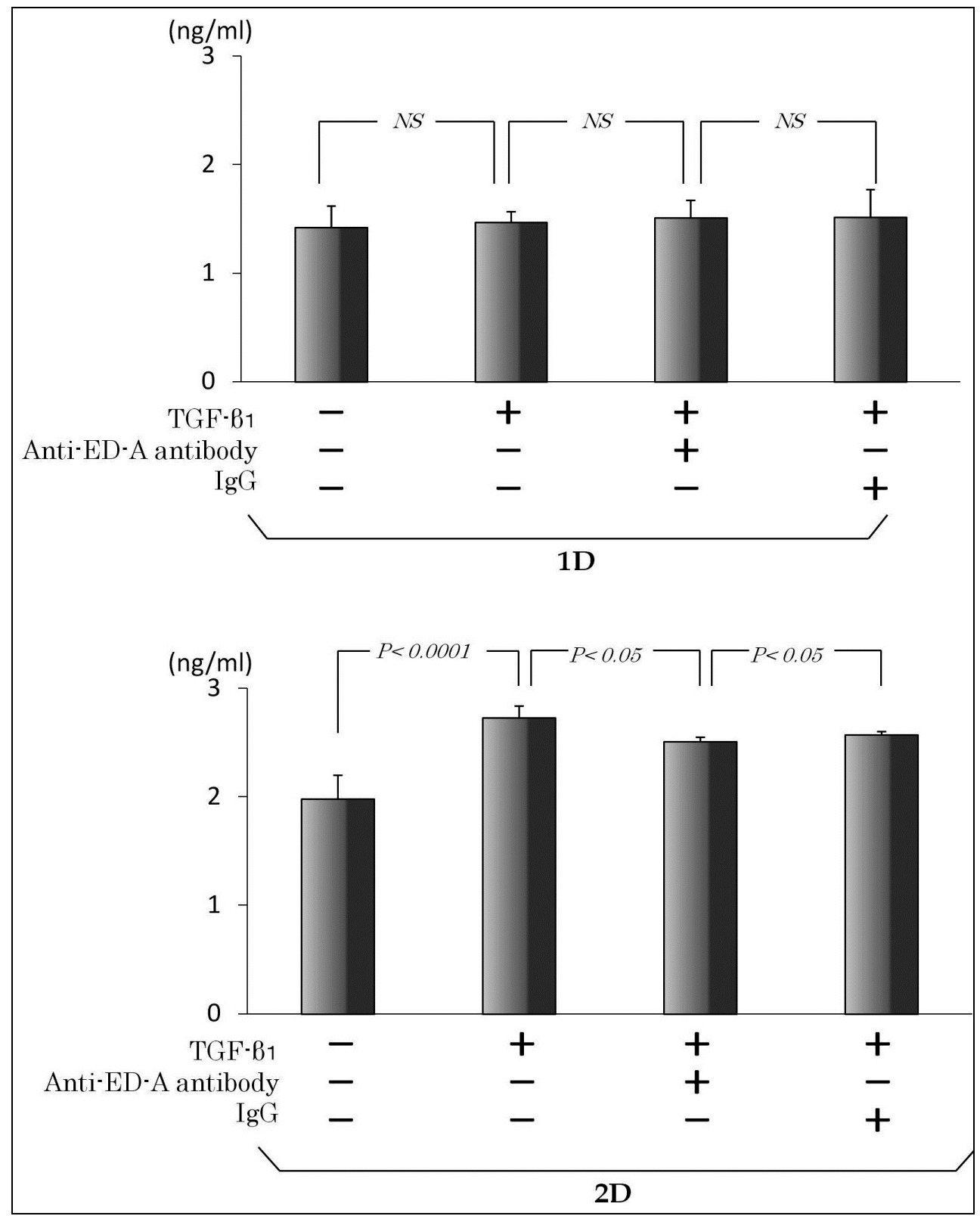

Fig. 6. Type I collagen accumulated in the supernatants of the monolayer cultures.

The TGF- $\beta_{1}$ and anti-ED-A antibodies do not influence the type I collagen accumulation in $1 \mathrm{D}$ groups. TGF- $\beta_{1}$ increased the type I collagen accumulation in the $2 \mathrm{D}$ TGF- $\beta_{1}$ and IgG groups. The TGF- $\beta_{1}$ - accelerated collagen accumulation was repressed by the anti-ED-A antibody. 
that a-SMA contributes to the progression of fibrosis, but do add an additional role for aSMA producing cells. There was another report (Leemans et al., 2009) that suggested that renal fibrogenesis persists despite decreasing numbers of a-SMA ${ }^{+}$myofibroblasts. This also does not contradict the general consensus about the role of myofibroblasts, because it can be considered that after myofibroblasts induce the accumulation of collagen fibrils by forming rigid fibrils which are resistant to proteolysis by proteinases, they undergo apoptosis. Subsequently, the a-SMA- fibroblasts might add collagen fibers to these rigid fibers. In this case, myofibroblasts would make up the nucleus of the accumulated collagen fibrils.

In the present study, TGF- $\beta_{1}$ induced the production of fibronectin ED-A, which was anchored to kidney fibroblasts, and subsequently induced a-SMA expression in the stress fiber formations in cells. Stress fiber formation is involved in cell contraction, which results in gel contraction via the consecutive binding of a-SMA, focal adhesion, integrins, and type I collagen. In addition, the a-SMA expression was strongly inhibited by exposing the cells to an anti-ED-A antibody. Therefore, the TGF- $\beta_{1}$-induced expression of a-SMA was considered to be, at least to a large extent, dependent on ED-A expression. This is compatible with the fact that the fibronectin ED-A isoform contributes to the transdifferentiation of a variety of cells into myofibroblasts with a-SMA (Bochaton-Piallat et al., 2000; Ffrench-Constant et al., 1989; Jamagin et al., 1994).

It was shown in the renal fibroblasts that the intracellular signaling pathways of TGF- $\beta_{1}$ induced fibronectin ED-A expression involves Smad 3 (Bondi et al., 2010). The pathways leading to a-SMA expression and myofibroblast transdifferentiation differed between reports. Our previous report suggested that the pathway of TGF- $\beta_{1}$-induced a-SMA expression involved p38 MAPK (Ina et al., 2011). This finding is consistent with a study by Miura et al. (Miura et al., 2006), in which retinal pigment epithelial cells were used. On the other hand, Masszi et al. (Masszi et al., 2003) have found that the activation of the Rho kinase pathway was involved in the a-SMA expression in renal tubular epithelial cells. The contrast between these findings might be due to the differences in the cells used. How ED-A expression activated the p38 MAPK pathway in the present study remains to be determined. However, ED-A has been identified as an endogenous ligand for Toll-like receptor-4 (Gondokaryono et al., 2007; Lefebvre et al., 2011; Ricupero et al., 2001) which is well known to be expressed in inflammatory cells such as macrophages, mast cells, and leukocytes, and is associated with innate immunity. Recently, it was demonstrated that Toll-like receptor 4 is also expressed in renal interstitial fibroblasts (Sorensen et al., 2011). Furthermore, the activation of Toll-like receptor 4 was reported to promote renal tubulointerstitial fibrosis (Campbell et al., 2011; Sorensen et al., 2011). It is therefore possible that ED-A binds to Tolllike receptor 4 and activates it, leading to stimulation of the related signaling pathways, eventually promoting the signaling by TGF- $\beta_{1}$ and stimulating a-SMA expression.

Because the immunostaining for fibronectin ED-A was positive in both conventional immunocytochemistry and in that without the first antibody (the anti-ED-A antibody) of the cells exposed to the antibody in culture, the epitope appears to be present in a region other than the receptor-binding site. In this case, the binding of the antibody to the epitope might cause alterations in the conformation of the receptor binding site, and inhibit the binding of ED-A to the receptor. In the current study, since contraction of the NRK49F cell-populated collagen lattice was suppressed by the adding anti-ED-A antibody, the ED-A expression was considered to be involved in TGF- $\beta_{1}$-induced gel contraction. 


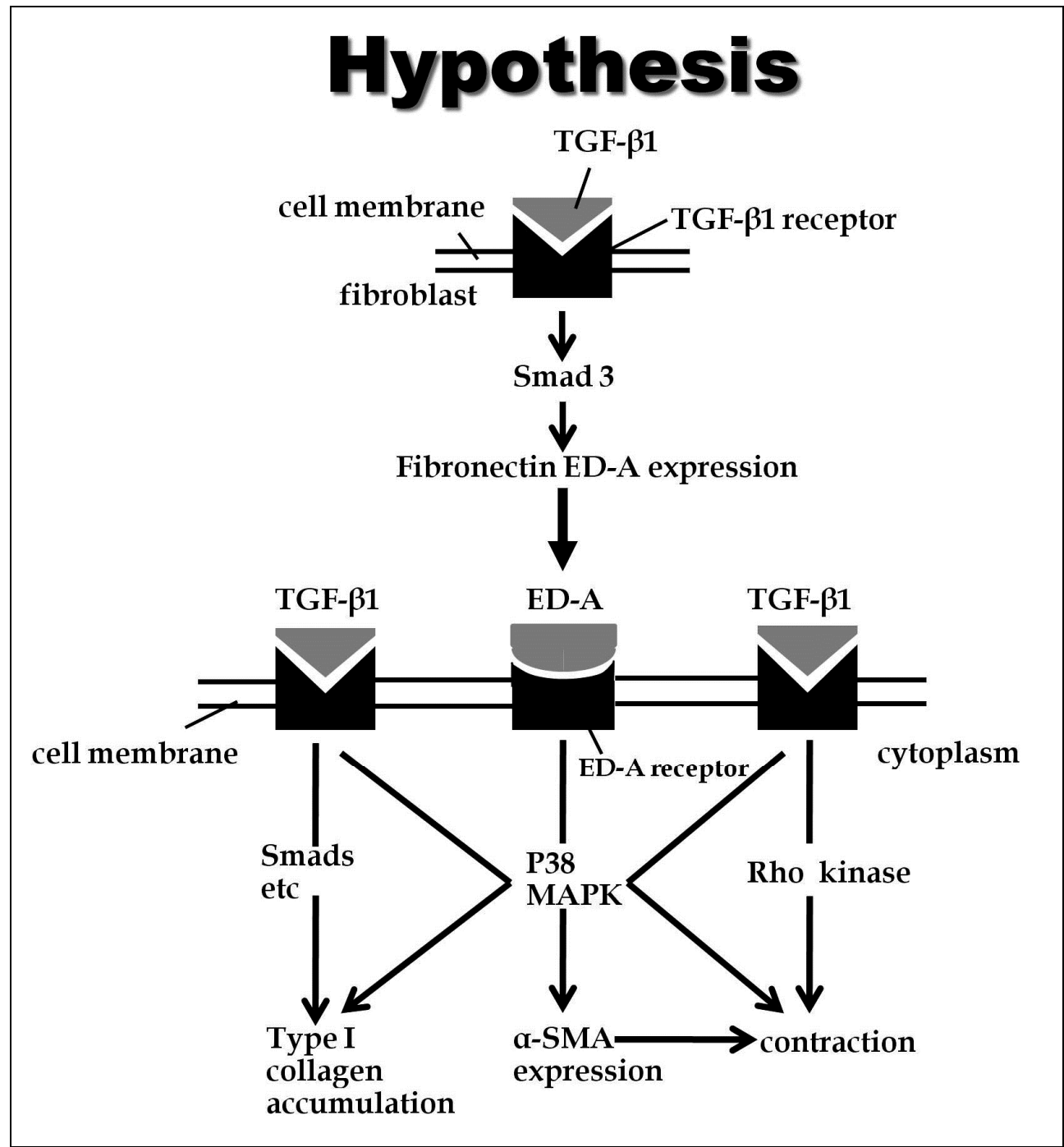

Fig. 7. The hypothesis: about the contribution of fibronectin ED-A expression to a-SMA expression and type I collagen accumulation.

We hypothesize the mechanism ad follows: TGF- $\beta_{1}$ induces ED-A domain expression through the pathway involving Smad 3 in the fibronectin molecule. The fibronectin ED-A is anchored to the cell via a combination of the cell-binding domain and the integrin on the cell. Subsequently, the ED-A domain binds to the receptor (the Toll-like receptor) and stimulates it. Furthermore, the signaling transfers to one of the TGF- $\beta_{1}$-activated pathways, which may be the p38 MAPK pathway. Finally, the ED-A-stimulated pathway induces aSMA expression and type I collagen accumulation, which involves the increased synthesis of collagen and decreased degradation of collagen via the production of proteinase inhibitors, TIMPs and PAI-1. 
The previous study demonstrated that TGF- $\beta_{1}$ caused the contraction of the fibroblast (without a-SMA expression)-populated collagen lattice in culture medium with $10 \%$ FBS. The TGF- $\beta_{1}$-induced gel contraction was accelerated by expressing a-SMA, which was induced by a low concentration of FBS and the addition of TGF- $\beta_{1}$ (Ina et al., 2011). Therefore, TGF- $\beta_{1}$ was suggested to exert distinct functions on a-SMA expression and gel contraction. In addition, it was shown that TGF- $\beta_{1}$-induced gel contraction occurred via the p38 MAPK pathway and the Rho kinase pathway (Ina et al., 2011). Taken together, since the p38 MARK pathway is involved in both a-SMA expression and gel contraction, it is likely that ED-A expression might stimulate the p38 MAPK pathway activated by TGF- $\beta_{1}$, followed by myofibroblast transdifferentiation and gel contraction.

These findings still have not clarified what gel contraction means in the fibrosis of diabetic nephropathy. We believe that it corresponds to the renal atrophy following fibrosis. However, it is also possible that gel contraction might reflect the shrinkage of collagen fibrils, allowing collagen molecules to become nearer to each other, followed by increased crosslinking, which leads to the formation of rigid fibrils. These are resistant to proteolysis by proteinases, thus leading to the accumulation of fibrils, and therefore, fibrosis.

In the present study, we also demonstrated that accumulation of type I collagen was, at least in part, dependent on ED-A expression. To our knowledge, this is the first report that ED-A mediates TGF- $\beta_{1}$-stimulated type I collagen accumulation, while there was a previous report that ED-A stimulated type I collagen mRNA expression (Serini et al., 1998). There are both Smad-dependent and independent pathways, including the p38 MAPK pathway, via which TGF- $\beta_{1}$ can stimulate the production of ECM containing type I collagen (Eickelberg, 2001). The observed a-SMA expression, gel contraction, and type I collagen accumulation are, at least in part, dependent on ED-A expression. The a-SMA expression was the most dependent of these events on ED-A. We therefore hypothesized that a-SMA expression is, to a large extent, dependent on ED-A expression via the p38 MAPK pathway. On the other hand, gel contraction and type I collagen accumulation were, to a lesser extent, dependent on ED-A expression, because they are comparatively mediated by pathways other than the p38 MAPK pathway. ED-A binds to Toll-like receptor- 4 and activates it, followed by signaling via diverse pathways in inflammatory cells (Akira \& Takeda, 2004). The p38 MAPK pathway is also included in these pathways. Thus, it is most likely that the a-SMA expression, gel contraction, and type I collagen accumulation induced by ED-A expression are mediated by activating the p38 MAPK pathway (Fig. 6). In other words, ED-A appears to enhance the activity of the p38 MARK pathway stimulated by TGF- $\beta_{1}$.

\section{Conclusion}

The TGF- $\beta_{1}$-induced a-SMA expression, followed by gel contraction and stimulated type I collagen accumulation, were, at least in part, dependent on fibronectin ED-A expression. These findings suggest that tubulointerstitial fibrosis associated with diabetic nephropathy and fibrotic tissue contraction leading to renal atrophy are partly mediated by TGF- $\beta_{1}$-induced fibronectin ED-A expression. In addition, since the fibronectin ED-A isoform is seldom found in normal adult subjects, the negative effects induced by 
inhibition of ED-A expression or activity would likely be minimal. Taken together, our findings and those of previous studies suggest that ED-A may be a target for treatment of diabetic nephropathy.

\section{Acknowledgement}

The authors thank Ms. Yukari Goto for her excellent secretarial assistance.

\section{References}

Akira, S., \& Takeda, K. (2004) .Toll-like receptor signaling. Nature Reviews, Vol. 4, pp. 499511, 1474-1733

Balza, E.L., Borsi, G., Allemmanni, G., \& Zardi, L. (1988). Transforming growth factor $\beta$ regulates the levels of different fibronectin isoforms in normal cultured fibroblasts. FEBS Letters, Vol. 228, pp. 42-44, 0014-5793

Bohle, A., Wehrmann, M., Bogenschtz, O., Batz, C., \& Muller, G.A. (1991). The pathogenesis of chronic renal failure in diabetic nephropathy. Pathology, Research and Practice, Vol. 187, pp. 251-259, 0344-0338

Bochaton-Piallat, M.L., Kapetanios, A.D., Donati, G., Redard, M., Gabbiani, G., \& Pournaras, C.J. (2000). TGF $-\beta 1$,

TGF- $\beta$ receptor II and ED-A fibronectin expression in myofibroblast of vitreoretinopathy. Investigation Ophthalmology \& Visual Science, Vol. 41, No.8, pp. 2336-2342, 1552-5783

Bondi, C.D., Manickam, N., Lee, D.Y., Block, K., Gorin, Y., Abboud, H.E., \& Barnes, J.L. (2010). NAD $(\mathrm{P}) \mathrm{H}$ oxidase mediates TGF- $\beta_{1}$-induced activation of kidney myofibroblasts. Journal of the American Society of Nephrology, Vol. 21, pp.93-102, 1046-6673

Borsi, L., Castellani, P., Risso, A.M., Leprini, A., \& Zardi, L. (1990). Transforming growth factor $\beta$ regulates the splicing pattern of fibronectin messenger RNA precursor. FEBS Letters, Vol. 261, pp. 175-178, 0014-5793

Campbell, M.T., Hile, K.L., Zhang, H., Asanuma, H., Vanderbrink, B.A., Rink, R.R., \& Meldrum, K.K. (2011). Toll-like receptor 4: a novel signaling pathway during renal fibrogenesis. Journal of Surgical Research, Vol. 168, No. 1, pp. e61-e69, 00224804

Edwards, D.R., Murphy, G., Reynolds, J.J., Whitham, S.E., Docherty, A.J.P., Angel, P., \& Heath, J.K. (1987). Transforming growth factor beta modulates the expression of collagenase and metalloprotease inhibitor. EMBO Journal, Vol. 6, pp. 1899-1904, 0261-4189

Eickelberg, O. (2001). Endless healing: TGF- $\beta$, SMADs, and fibrosis. FEBS Letters, Vol. 506, pp. 11-14, 0014-5793

Ffrench-Constant, C., Van, W.L., Dvorak, H.F., \& Hynes, R.O. (1989). Reappearance of an embryonic pattern of fibronectin splicing during wound healing in the adult rat. The Journal of Cell Biology, Vol. 109, pp. 903-914, 0021-9525 
Gabbiani, G. \&, Ryan, G., \& Majno, G. (1971). Presence of modified fibroblasts in granulation tissue and their possible in wound contraction. Experientia, Vol. 27, pp. 549-550, 0014-4754

Glukhova, M.A., Frid, M.G., Shekhomin, B.V., Vasilevskaya, T.D., Grunwald, J., Saginati, M., \& Koteliansky, V.E. (1989). Expression of extra domain-A fibronectin sequence in vascular smooth muscle cells is phenotype dependent. The Journal of Cell Biology, Vol. 109, pp. 357-366, 0021-9525

Gondokaryono, S.P., Ushio, H., Niyonsaba, F., Hara, M., Takenaka, H., Jayawardana, S.T.M., Ikeda, S., Okumura, K., \& Ogawa, H. (2007). The extra domain A of fibronectin stimulates murine mast cells via Toll-like receptor 4. Journal of Leukocyte Biology, Vol. 82, pp. 657-665, 1938-3673

Humphreys, B.D., Lin, S.L., Kobayashi, A., Hudson, T.E., Nowlin, B.T., Bonventre, J.V., Valerius, M.T., McMahon, A.P., \& Duffield, J.S. (2010). Fate tracing reveals the pericyte and not epithelial origin of myofibroblasts in kidney fibrosis. The American Journal of Pathology, Vol. 176, pp. 85-97, 0002-9440

Ina, K., Kitamura, H., Tatsukawa, S., \& Fujikura, Y. (2011). Significance of a-SMA in myofibroblasts emerging in renal tubulointerstitial fibrosis. Histology and Histopathology, Vol. 26, pp. 855-866, 1699-5848

Iwano, M., Plieth, D., Danoff, T.M., Xue, C., Okeda, H., \& Neilson, E.G. (2002). Evidence that fibroblasts derive from epithelium during tissue fibrosis. The Journal of Clinical Investigation, Vol. 110, pp. 341-350, 0021-9738

Jamagin, W.R., Rockey, D.C., Koteliansky, V.E., Wang, S.S., \& Bissel, D.M. (1994). Expression of variant fibronectins in wound healing: Cellular source and biological activity of the ElllA segment in rat hepatic fibrogenesis. The Journal of Cell Biology, Vol. 127, pp. 2037-2048, 0021-9525

Keeley, E.C., Mehrad, B., \& Strieter, R.M. (2010). Fibrocytes: bringing new insights into mechanisms of inflammation and fibrosis. The International Journal of Biochemistry $\mathcal{E}$ Cell Biology, Vol. 42, pp. 535-542, 1357-2725

Laiho, M., Saksela, O., \& Keski-Oja, J. (1987). Transforming growth factor- $\beta$ induction of type-1 plasminogen activator inhibitor. Journal of Biological Chemistry, Vol. 262, pp. 17467-17474, 0021-9258

Leemans, J.C., Butter, L.M., Pulskens, W.P., Teske, G.J., Claessen, N., V.d.Poll, T., \& Florequin, S. (2009). The role of Toll-like receptor 2 in inflammation and fibrosis during progressive renal injury. PLoS ONE, Vol. 4, pp. e5704, 1932-6203

Lefebvre, J.S., Lévesque, T., Picard, S., Paré, G., Gravel, A., Flamand, L., \& Borgeat, P. (2011). Extra domain A of fibronectin primes leukotriene biosynthesis and stimulates neutrophil migration through activation of Toll-like receptor 4. Arthritis $\mathcal{E}$ Rheumatism, Vol. 63, No.6, pp. 1527-1533, 1529-0131

Magnusson, M.K., \& Mosher. D.F. (1998). Fibronectin: Structure, assembly, and cardiovascular implications. Arteriosclerosis, Thrombosis, and Vascular Biology, Vol. 18, pp. 1363-1370, 0276-5047

Masszi, A., Ciano, C.D., Sirokmány, G., Arthur, W.T., Rotstein, O.D., Wang, J., McCulloch, C.A.G., Rosivall, L., Mucsi, I., \& Kapus, A. (2003). Central role for Rho in TGF- $\beta 1$ induced a-smooth muscle actin expression during epithelial-mesenchymal 
transition. American Journal of Physiology-Renal Physiology, Vol. 284, No. 5, pp. F911F924, 1522-1466

Miura, M., Hata, H., Hirayama, K., Kita, T., Noda, Y., Fujisawa, K., Shimokawa, H., \& Ishibashi, T. (2006). Critical role of the Rho-kinase pathway in TGF- $\beta 2$-dependent collagen gel contraction by retinal pigment epithelial cells. Experimental Eye Research, Vol. 82, pp. 849-859, 0014-4835

Norton, P.A., \& Hynes, R.O. (1987). Alternative splicing of chicken fibronectin in embryos and in normal and transformed cells. Molecular and Cellular Biology, Vol. 7, pp. 42974307

Petersen, T.E., Thogersen, H.C., Skorstengaard, K., Vibe-Pedersen, K., Sahi, P., SottrupJensen, L., \& Magnusson, S. (1983). Partial primary structure of bovine plasma fibronectin: Three types of internal homology. Proceedings of the National Academy of Sciences of the United States of America, Vol .80, pp. 137-141, 0027-8424

Ricupero, D.A., Poliks, C.F., Rishikof, D.C., Kuang, P-P., \& Goldstein, R.H. (2001). Apigenin decreases expression of the myofibroblast phenotype. FEBS Letters, Vol. 506, pp. 1521, I0014-5793

Serini, G., Bochaton-Piallat, M.L., Ropraz, P., Geinoz, A., Borsi, L., Zardi, L., \& Gabbiani, G. (1998). The fibronectin domain ED-A is crucial for myofibroblastic phenotype induction by transforming growth factor- $\beta 1$. The Journal of Cell Biology, Vol. 142, No.3, pp. 873-881, 0021-9525

Simonson, M.S. (2007). Phenotypic transitions and fibrosis in diabetic nephropathy. Kidney International, Vol. 71, pp. 846-854, 0085-2538

Sörensen, I., Susnik, N., Inhester, T., Degen, J.L., Melk, A., Haller, H., \& Schmitt, R (2011). Fibrinogen, acting as a mitogen for tubulointerstitial fibroblasts, promotes renal fibrosis. Kidney International, [epub ahead of print], 0085-2539

Strutz, F., \& Zeisberg, M. (2006). Renal fibroblasts and myofibroblasts in chronic kidney disease. The Journal of American Society of Nephrology, Vol. 17, pp. 2992-2998, 10466673

Takeji, M., Moriyama, T., Oseto, S., Kawada, N., Hori, M., Imai, E., \& Miwa, T. (2006). Smooth muscle a-actin deficiency in myofibroblasts leads to enhanced renal tissue fibrosis. Journal of Biological Chemistry, Vol. 281, pp. 40193-40200, 1083$351 X$

Tomasek, J.J., Gabbiani, G., Hinz, B., Chaponnier, C., \& Brown, R.A. (2002). Myofibroblasts and mechano-regulation of connective tissue remodeling. National Reviews Molecular Cell Biology, Vol. 3, No. 5, pp. 349-363, 1471-0072

Vartio, T., Laitinen, L., Narvanen, O., Cutolo, M., Thornell, L.E., Zardi, L., \&Virtanen, I. (1987). Differential expression of the ED sequence-containing form of cellular fibronectin in embryonic and adult human tissues. Journal of Cell Science, Vol. 88, pp. 419-430, 1477-9137

Wierzbicka-Patynowski, I., \& Schwarzbauer, J.E. (2003). The ins and outs of fibronectin matrix assembly. Journal of cell Science, Vol. 116, pp. 3269-3276, 1477-9137 
Zeisberg, E.M., Potenta, S.E., Sugimono, H., Zeisberg, M., \& Kalluri, R. (2008). Fibroblasts in kidney fibrosis emerge via endothelial-to-mesenchymal transition. The Journal of American Society of Nephrology, Vol. 19, pp. 2282-2287, 1046-6673 


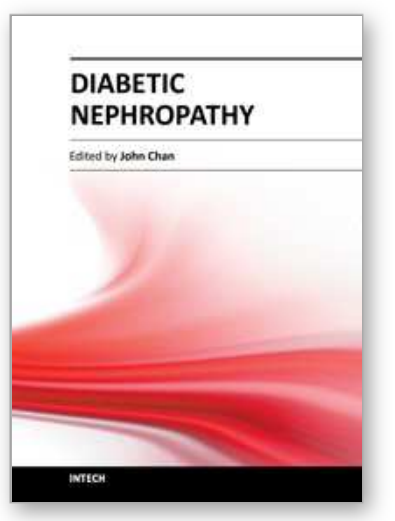

\author{
Diabetic Nephropathy \\ Edited by Dr. John Chan
}

ISBN 978-953-51-0543-5

Hard cover, 166 pages

Publisher InTech

Published online 20, April, 2012

Published in print edition April, 2012

Internationally renowned experts have provided data on their own studies, and discuss the relative usefulness of their work in relation to diabetic nephropathy. The first section describes the novel role of intrarenal reninangiotensin-aldosterone system (RAAS) and oxidative stress in the development of diabetic nephropathy and discusses the current and novel pharmacological interventions in the treatment of diabetic nephropathy. The second section discusses other important contributors outside of the RAAS in the pathogenesis of diabetic nephropathy including AGE/RAGE, epithelial-mesenchymal-transition (EMT) and immune cytokines. Features: Provides novel information on various pathophysiological determinants in the development of diabetic nephropathy Provides novel information on various pharmacological interventions of diabetic nephropathy

\title{
How to reference
}

In order to correctly reference this scholarly work, feel free to copy and paste the following:

Keisuke Ina, Hirokazu Kitamura, Shuji Tatsukawa and Yoshihisa Fujikura (2012). The Contribution of Fibronectin ED-A Expression to Myofibroblast Transdifferentiation in Diabetic Renal Fibrosis, Diabetic Nephropathy, Dr. John Chan (Ed.), ISBN: 978-953-51-0543-5, InTech, Available from: http://www.intechopen.com/books/diabetic-nephropathy/contribution-of-fn-ed-a-expression-to-myofibroblasttransdifferentiation-in-diabetic-renal-fibrosis-

\section{INTECH}

open science | open minds

\author{
InTech Europe \\ University Campus STeP Ri \\ Slavka Krautzeka 83/A \\ 51000 Rijeka, Croatia \\ Phone: +385 (51) 770447 \\ Fax: +385 (51) 686166 \\ www.intechopen.com
}

\author{
InTech China \\ Unit 405, Office Block, Hotel Equatorial Shanghai \\ No.65, Yan An Road (West), Shanghai, 200040, China \\ 中国上海市延安西路65号上海国际贵都大饭店办公楼 405 单元 \\ Phone: +86-21-62489820 \\ Fax: $+86-21-62489821$
}


(C) 2012 The Author(s). Licensee IntechOpen. This is an open access article distributed under the terms of the Creative Commons Attribution 3.0 License, which permits unrestricted use, distribution, and reproduction in any medium, provided the original work is properly cited. 